\title{
Archaeological Facial Depiction for People from the Past with Facial Differences Caroline Wilkinson
}

\section{Introduction}

The significance of the face in the acquisition of a physical and psychological self and in social interaction can hardly be overestimated. The face indicates gender, age, ancestry, health, mood, emotion, and even perhaps character and personality and, as a 'mirror to the soul', it permeates the very fabric of human experience. ${ }^{1}$ The face has the power to cause reference beyond itself and yet to be the central site of signification. ${ }^{2}$ Our faces help us understand who we are and where we come from, ${ }^{3}$ and the 'unveiling of the soul' that results from the consideration of pure appearance reveals an understanding that we see more than we take in. ${ }^{4}$ It is well-established that the face is the primary determinant in the perception of attractiveness and that this perception is key to self-esteem and life opportunities. We know that humans have a cognitive bias towards attractive people and 'good-looking' people have

\footnotetext{
${ }^{1}$ A. Synnott, A. 'Truth and Goodness, Mirrors and Masks, Part 1: A Sociology of Beauty and
} the Face', The British Journal of Sociology 40.4 (1989): 607-36.

${ }^{2}$ J. T. Siegel, 'George Simmel Reappears: "The Aesthetic Significance of the Face"”, Diacritics 29.2 (1999): 100-113.

${ }^{3}$ N. Rumsey, 'Psychological Aspects of Face Transplantation: Read the Small Print Carefully', American Journal of Bioethics 4.3 (2004): 22-5.

${ }^{4}$ Siegel, 'George Simmel'. 
higher incomes, ${ }^{5}$ are judged to have good personality qualities, ${ }^{6}$ are thought to be less likely criminals, ${ }^{7}$ receive less severe sentences for criminal convictions, ${ }^{8}$ are more likely to be called to job interview, ${ }^{9}$ and have higher mating success. ${ }^{10}$ In addition attractiveness has been shown to be related to higher social status, ${ }^{11}$ and we make rapid, unreflective judgments on

${ }^{5}$ J. Kaczorowski, 'The Good, the Average and the Ugly: Socio-Economic Dimensions of Physical Attractiveness'. MA Thesis, Dept of Sociology, McGill University, Montreal, 1989. ${ }^{6}$ D. S. Berry, 'Attractive Faces are not all Created Equal: Joint Effects of Facial Babyishness and Attractiveness on Social Perception', Personality and Social Psychology Bulletin 17.5 (1991): 523-31; D. Bar-Tal and L. Saxe, 'Perceptions of Similarly and Dissimilarly Attractive Couples and Individuals', Journal of Personality and Social Psychology 33.6 (1976), 772.

${ }^{7}$ O. H. MacLin and M. K. MacLin, 'The Effect of Criminality on Face Attractiveness, Typicality, Memorability and Recognition', North American Journal of Psychology 6.1 (2004): $145-54$

${ }^{8}$ K. L. Wuensch, W. A. Castellow and C. H. Moore, 'Effects of Defendant Attractiveness and Type of Crime on Juridic Judgement', Journal of Social Behaviour and Personality 6.4 (1991), 713.

${ }^{9}$ F. L. Bóo, M. A. Rossi and S. S. Urzúa, 'The Labor Market Return to an Attractive Face: Evidence from a Field Experiment', Economics Letters 118.1 (2013), 170-172.

${ }^{10}$ G. Rhodes, L. W. Simmons and M. Peters, 'Attractiveness and Sexual Behavior: Does Attractiveness Enhance Mating Success?' Evolution and Human Behavior 26.2 (2005): 186201.

${ }^{11}$ C. Anderson, O P. John, D. Keltner and A. M. Kring, 'Who Attains Social Status? Effects of Personality and Physical Attractiveness in Social Groups', Journal of Personality and Social Psychology 81.1 (2001), 116. 
competence, aggression and leadership qualities based on facial appearance. ${ }^{12}$ Therefore, facial appearance appears to be crucial to power, status, resilience and reputation. Is it little wonder, then, that we desire to see the faces of people from the past and make similar judgements on their identity, personality and character?

Since the face is fundamental to identity, status and reputation, facial difference (such as malocclusion and deformity) has been shown to reduce opportunity and success. This is, in large part, due to perceptions of lower intelligence, ${ }^{13}$ lower attractiveness ${ }^{14}$ and higher

${ }^{12}$ Respectively, A. Todorov, A. N. Mandisodza, A. Goren and C. C. Hall, 'Inferences of Competence from Faces Predict Election Outcomes', Science 308 (5728): 1623-6; J. M. Carré and C. M. McCormick, 'In Your Face: Facial Metrics Predict Aggressive Behaviour in the Laboratory and in Varsity and Professional Hockey Players', Proceedings of the Royal Sociaety of London B: Biological Sciences 275 (1651) (2008), 2651-6; N. O. Rule and N. Ambady, 'The Face of Success: Inferences from Chief Executive Officers' Appearance Predict Company Profits', Psychological Science 19 (2008), 109-111. See also, however, chapters 4 and 7 in the present volume, which expose some of the underlying assumptions of such studies, and propose more nuanced approaches.

${ }^{13}$ L. C. Richman, 'The Effects of Facial Disfigurement on Teachers' Perception of Ability in Cleft Palate Children', Cleft Palate Journal 15 (1978), 155-160; A. Jesani, A. T. DiBase, M. T. Cobourne and T. Newton, 'Perceived Changes by Peer Group of Social Impact Associated with Combined Orthodontic-Surgical Correction of Class III Malocclusion', Journal of Dentistry 42.9 (2014), 1135-1142.

${ }^{14}$ W. J. S. Kerr and J. M. O’Donnell, 'Panel Perception of Facial Attractiveness', British Journal of Orthodontics 17.4 (1990), 299-304; Jesani et al., 'Perceived Changes'. 
criminal behaviour, ${ }^{15}$ leading to increased social isolation ${ }^{16}$ and bullying. ${ }^{17}$ Facial appearance was also critical in ancient populations, where it is suggested that facial disfigurement resulted in a diminished social status. ${ }^{18}$

Facial depiction from human remains is now commonplace in archaeological investigations, and allows us to visualise faces from the past, compare ancient faces with contemporary cohorts and make judgements on status, character and lifestyle. Facial depiction from skeletal remains has primarily been applied in forensic investigations, when other approaches are not possible or few clues are available to aid in the identification. ${ }^{19}$ The technique is used to rebuild a face onto a skull to recreate the ante-mortem appearance of the individual in order

${ }^{15}$ R. Bull, 'The Psychological Significance of Facial Deformity', in Love and Attraction: an International Conference. 1 (Oxford and Toronto: Pergamon Press, 1979), 21-5.

${ }^{16}$ N. Rumsey, R. Bull and D. Gahagan, 'The Effect of Facial Disfigurement on the Proxemic Behavior of the General Public', Journal of Applied Psychology 12.2 (1982), 137-50; V. Houston and R. Bull, 'Do People Avoid Sitting Next to Someone who is Facially Disfigured?' European Journal of Social Psychology 24.2 (1994), 279-284.

${ }^{17}$ N. Rumsey and D. Harcourt, 'Body Image and Disfigurement: Issues and Interventions', Body Image 1.1 (2004): 83-97.

${ }^{18}$ E. Craig and G. Craig, 'The Diagnosis and Context of Facial Deformity from an AngloSaxon Cemetery at Spofforth, North Yorkshire', International Journal of Osteoarchaeology $23.6(2013), 631-9$.

${ }^{19}$ C. M. Wilkinson, Forensic Facial Reconstruction (Cambridge: Cambridge University Press, 2004) 
to recognise and identify the decedent. ${ }^{20}$ The methods utilised for facial depiction from skeletal remains are well described and tested, and are based on anatomical standards, craniometrics and morphological interpretation. ${ }^{21}$ It is widely accepted that the first scientific facial depiction from skeletal remains was attempted by the German anatomist, Wilhelm His, who rebuilt the face of the composer Johann Sebastian Bach in order to authenticate his remains. ${ }^{22}$ Thereafter, the demand for facial depiction in archaeological research has increased and interdisciplinary studies have been performed world-wide to rebuild faces from the past. ${ }^{23}$ Faces of historical figures have been depicted from skeletal analysis and previous

${ }^{20}$ Wilkinson, Forensic Facial Reconstruction.

${ }^{21}$ C. Wilkinson, C. Rynn, H. Peters, M. Taister, C. H. Kau and S. Richmond, 'A Blind Accuracy Assessment of Computer-Modelled Forensic Facial Reconstruction using Computer Tomography Data from Live Subjects', Forensic Science, Medicine and Pathology 2.3 (2006), 179-187; C. Wilkinson, 'Facial Reconstruction: Anatomical Art or Artistic Anatomy?' Journal of Anatomy 216.2 (2010), 235-50; W. J. Lee, C. M. Wilkinson and H. S. Hwang, 'An Accuracy Assessment of Forensic Computerized Facial Reconstruction Employing Cone-Beam Computed tomography from Live Subjects', Journal of Forensic Sciences 57.2 (2012), 318-27.

${ }^{22}$ W. His, Johann Sebastian Bach: Forschungen uber dessen Brabstatte, Bebeine und Antlitz (Leipzig: F. C. W. Vogel, 1895).

${ }^{23}$ F. Cesarani, M. C. Martina, R. Gilletto, R. Boano, A. M. D. Roveri, V. Capussotto, A. Giuliano, M. Celia and G. Gandini, 'Facial Reconstruction of a Wrapped Egyption Mummy using MDCT', American Journal of Roentgenology 183 (2004), 755-8; M. Gregersen, J. Boldsen, H. Björn, L. W. Boel and P. Fromholt, 'Examination and Identification of a Danish $17^{\text {th }}$-Century Nobleman, Laurids Ebbesen: a Multi-Disciplinary Study', Forensic Science and 
examples have contributed to the changing views of the media and the public in relation to these historical figures. Cases include the face of Richard III, ${ }^{24}$ Henri IV,${ }^{25}$ Nefertiti and Tutankhamun. ${ }^{26}$ In the case of Richard III, the King was depicted as an ordinary man, without the monstrous deformity or embodiment of evil suggested by Shakespeare, and this

Medical Pathology 2 (2006), 51-8; C. Wilkinson, 'The Facial Reconstruction of Ancient Egyptians', in Egyptian Mummies and Modern Science, ed. R. David (Cambridge: Cambridge University Press, 2008), 162-180; M. J. Papagrigorakis, P. N. Synodinos, A. Antoniadis, E. Maravelakis, P. Toulas, O. Nillson and E. Baziotopoulou-Valavani, 'Facial Reconstruction of an 11-Year-Old Female Resident of 430BC Athens', The Angle Orthodontist 81 (2011), 171-9.

${ }^{24}$ C. Wilkinson, 'The Man Himself: the Face of Richard III', The Ricardian Bulletin (Sept 2013), 50-5.

${ }^{25}$ H. Samuel, 'Face of France's Good King Henri IV Reconstructed 400 Years After his Death', The Telegraph (14 February 2013).

http://www.telegraph.co.uk/news/worldnews/europe/9870454/Face-of-Frances-Good-KingHenri-IV-reconstructed-400-years-after-his-death.html [accessed 31/3/2017].

${ }^{26}$ Respectively, T. Friend, 'Could this be the Profile of a Queen?' Race and History Forum, USA Today (15 August 2003), http://www.raceandhistory.com/cgibin/forum/webbbs config.pl?md=read;id=1368B; B. Handwerk, 'King Tut's New Face'. National Geographic News (11 May 2005), http://news/nationalgeographic.com/news/2005/05/photogalleries/tut_mummy/photo4.html [accessed 31/3/2017]. 
depiction informed the academic debate surrounding the King in relation to Tudor propaganda, demonization and historical inaccuracy. ${ }^{27}$

Over the years, there have been some facial reconstructions depicting healed facial trauma or disease, most notably that of Phillip II of Macedon with a healed battle wound across his left eye ${ }^{28}$ and Robert the Bruce with leprosy and a healed sword wound at his forehead. ${ }^{29}$ The incidence of facial difference in archaeological depictions is not recorded, but the visibility of facial difference in ancient populations must influence our opinions relating to people from the past. Therefore, this paper describes some depiction cases where facial difference has been demonstrated, and describes the effects of these depictions in the media and public domain.

\section{Healed trauma in archaeological facial depiction}

Examples of healed trauma on skulls from archaeological investigations are numerous and well documented. These include ante-mortem wounds attributed to battle, ${ }^{30}$ medical

${ }^{27}$ S. Pappas, 'Did Richard III really have a Friendly Face?' Live Science: History (8 February 2013). http://www.livescience.com/26959-richard-iii-friendly-face.html [accessed $31 / 3 / 2017]$

${ }^{28}$ J. H. Musgrave, R. A. H. Neave and A. J. N. W. Prag, 'The Skull from Tomb II at Vergina: King Philip II of Macedon', Journal of Hellenic Studies 104 (1984), 60-78.

${ }^{29}$ I. B. Macleod and B. Hill, Heads and Tales: Reconstructing Faces (Edinburgh: National Museums of Scotland, 2001).

${ }^{30}$ V. Fiorato, A. Boylston and C. Knüsel, Blood Red Roses: The Archaeology of a Mass Grave from the Battle of Towton, AD1461 (2 $2^{\text {nd }}$ edition, Oxford: Oxbow Books, 2007); T. 
treatment, ${ }^{31}$ accidents ${ }^{32}$ and interpersonal violence. ${ }^{33}$ However, there is a much smaller number of individuals with healed wounds (ante-mortem) to the face, where a facial depiction has been produced as part of the archaeological investigation.

Anderson and I. Hodgkins, 'Healed Cranial Weapon Injury from Medieval Coventry, England', Neurosurgery 50.4 (2002), 870-3; A. Kjellström, ‘A Sixteenth-Century Warrior Grave from Uppsala, Sweden: the Battle of Good Friday', International Journal of Osteoarchaeology 15.1 (2005), 23-50; F. Kanz and K. Grossschmidt, 'Head Injuries of Roman Gladiators', Forensic Science International 160.2 (2006), 207-216.

${ }^{31}$ A. Nerlich, O. Peschel, A. Zink and F. W. Rösing, 'The Pathology of Trepanation: Differential Diagnosis, Healing and Dry Bone Appearance in Modern Cases', Trepanation History, Discovery, Theory 17 (2003), 43-51; N. D. Powers, 'Cranial Trauma and Treatment: a Case Study from the Medieval Cemetery of St Mary Spital, London', International Journal of Osteoarchaeology 15.1 (2005), 1-14.

${ }^{32}$ V. G. Standen and B. T. Arriaza, 'Trauma in the Preceramic Coastal Populations of Northern Chile: violence or Occupational Hazards?' American Journal of Physical Anthropology 112.2 (2000), 239-49; M. A. Judd, 'One Accident Too Many', British Museum Studies in Ancient Egypt and Sudan 3 (2002), 42-54.

${ }^{33}$ R. J. Schulting and M. Wysocki, 'In this Chambered Tumulus were found Cleft Skulls: an Assessment of the Evidence for Cranial Trauma in the British Neolithic', Proceedings of the Prehistoric Society 71 (2005), 107-138; L. Fibiger, T. Ahlström, P. Bennike and R. J. Schulting. 'Patterns of Violence-Related Skull Trauma in Neolithic Southern Scandinavia'. American Journal of Physical Anthropology 150.2 (2013), 190-202. 
Ante-mortem skeletal trauma has a different appearance to peri and post-mortem skeletal trauma, and is usually distinguished by signs of healing to the bone. The physical properties of bone change after death leading to different fracture characteristics; fresh or living bone is more pliable and more resistant to tensile forces, as it contains living vessels and fibres. Living bone tends to splinter and have irregular edges to fractures, whereas dried bone shatters into small, more regular fragments, as it is harder and more brittle. Furthermore, the concentric and radiating fracture lines, and stellate fractures normal for fresh bone do not occur in dry bone. ${ }^{34}$ In this way, anthropologists can distinguish between trauma at or around the time of death (peri-mortem), and trauma to dry bone due to the environment (postmortem). The time required for significant loss of organic and moisture content of bone depends on the post-mortem environment. ${ }^{35}$ However, ante-mortem wounds occur earlier in life and since they prove not to be lethal (or at least not right away) healing processes around the wound will be visible. Where an injury occurred at least a week before death there will be slight evidence of remodelling, ${ }^{36}$ and advanced healing is indicated by smooth remodelled

${ }^{34}$ W. R. Maples, 'Trauma Analysis by the Forensic Anthropologist', in Forensic Osteology: Advances in the Identification of Human Remains, ed. K. J. Reichs (Springfield, IL: Charles C. Thomas, 1986), 218-228; N. J. Sauer, 'The Timing of Injuries and Manner of Death: Distinguishing among Antemortem, Perimortem and Postmortem Trauma', In Forensic Osteology, ed. Reichs, 321-332; M. H. Kaufman, D. Whitaker and J. McTavish, 'Differential Diagnosis of Holes in the Calvarium: Application of Modern Clinical Data to Paleopathology', Journal of Archaeological Science 24 (1997), 193-218.

${ }^{35}$ E. R. Fitzgerald, 'Postmortem Transition in the Dynamic Mechanical Properties of Bone', Medical Physics 4 (1977), 49-53; Maples, 'Trauma Analysis'.

${ }^{36}$ Sauer, 'Timing of Injuries'. 
bone that often obscures the original injury. ${ }^{37}$ It is usually inappropriate for a facial reconstruction to depict the trauma associated with the death of the individual (unless the manner of death is the primary motivation for the depiction), but healed trauma will have affected the facial appearance of the individual during life and this is considered relevant to any facial depiction from skeletal remains.

One example of minor healed trauma can be seen in the depiction of St Nicholas. St Nicholas, also called Nikolaos of Myra, was a 4th-century Christian saint and Greek bishop. ${ }^{38} \mathrm{He}$ is credited with many miracles and his legendary habit of secret gift-giving lead to the traditional model of Santa Claus. ${ }^{39}$ The human remains of St Nicholas have been housed in the crypt of the Basilica di San Nicola, Bari, where they are contained in a sealed tomb. In the 1950s the crypt needed extensive work and the human remains were removed for the first and only time since they were interred by Pope Urban II in $1089 .{ }^{40}$ A special Pontifical Commission, led by Monsignor Enrico Nicodemo, archbishop of Bari, arranged for the examination of the relics to be carried out in the commission's presence. Luigi Martino, Professor of Human Anatomy at the University of Bari, was engaged to perform the

\footnotetext{
${ }^{37}$ Kanz and Grossschmidt, 'Head Injuries'.

${ }^{38}$ C. W. Jones, St Nicholas of Myra, Bari and Manhattan: Biography of a Legend (Chicago: University of Chicago Press, 1988).

${ }^{39}$ Ibid.

${ }^{40}$ St Nicholas Center (2002-2007) Anatomical Examination of the Bari Relics. http://www.stnicholascenter.org/pages/anatomical-examination/ [accessed 31/3/2017].
} 
examination. ${ }^{41}$ Both anatomical and anthropological examinations were performed, including detailed scientific drawings, photographs and x-rays, along with thousands of careful anatomical measurements. These examinations suggested a man over seventy years of age, of average height and slender-to-average build. The skeleton showed evidence that he suffered from severe chronic arthritis of the spine and pelvis. In 2004 a facial depiction from skeletal assessment was produced at the University of Manchester in collaboration with Professor Franco Introna, a pathologist from the University of Bari. ${ }^{42}$ The skull was recreated as a digital 3D model using the craniographs and drawings as templates and utilising the craniometrics and photographs to check the model and apply detail. The resulting skull model was then employed, along with the photographic records, in order to produce a facial depiction following the anatomical and morphological method. The assessment established that the skull exhibited a clear nasal bone fracture, causing a deviation of the nasal bridge to his right and a flattening of the nasal profile. This fracture demonstrated healed bone and was clearly an ante-mortem injury. An up-dated depiction was produced by Face Lab at Liverpool John Moores University in $2014 .{ }^{43}$ Texts relating to St Nicholas describes a man who

${ }^{41}$ L. Martino, 'Ricognizione anatomica a studo antropometrico delle reliquie ossee di San Nicola di Bari', Bollettino di San Nicola, Special Issue (April to December 1957), http://www.stnicholascenter.org/pages/anatomical-examination/ [accessed 31/3/2017]. ${ }^{42}$ P. Curtis, 'Researchers Find the Real Face of Father Christmas'. The Guardian (13 December 2004). https://wwwtheguardian.com/education/2004/dec/13/highereducation.uk [accessed 31/3/2017].

${ }^{43}$ I. Hughes, 'Is this the Real Face of Santa Claus? Presenting St Nicholas, the Inspiration for Father Christmas'. The Mirror (5 December 2015), http://www.mirror.co.uk/news/uknews/real-face-santa-claus-presenting-4755042 [accessed 31/3/2017]. 
suffered great persecution and imprisonment for his religion, and he was tortured and beaten during the years of his imprisonment. ${ }^{44}$ St Nicholas also destroyed pagan temples and confronted pagan worship, so he was not a stranger himself to violent action. The depiction of the healed trauma to the nose of St Nicholas was a feature noted by the media who, with reference to the historical documentation of his Christian persecution and torture, suggested that interpersonal violence was the most likely cause of his broken nose, and further promoted the view of St Nicholas as a robust and resilient bishop. ${ }^{45}$

Sometimes healed wounds can provide additional evidence of medical treatment and lifestyle in medieval periods. One such investigation related to the human remains of a soldier from the Battle of Towton, $1461 .{ }^{46}$ Towton 16 was a middle-aged (45-50 years) man with extensive peri-mortem (at or around the time of death) wounds to the forehead and temporal bones, probably delivered by a poleaxe. However, there was also a well-healed blade injury to the left body of the mandible: the wound was $65 \mathrm{~mm}$ in length running along the cheek, from the top of the third molar to the chin. The blade wound had penetrated the internal surface of the lower jaw, removing the apex of the first molar and impacting the internal surface of the other side of the mandible. A gaping hole remained between the left first and second molars where the bone had been removed. All margins of the wound were well healed

44 Jones, St Nicholas.

${ }^{45}$ B. Handwerk, 'St. Nicholas to Santa: The Surprising Origins of Mr. Claus', National Geographic (20 December 2013) http://news.nationalgeographic.com/news/2013/12/131219santa-claus-origin-history-christmas-facts-st-nicholas/ [accessed 31/3/2017].

${ }^{46}$ C. Wilkinson and R. Neave, 'The Reconstruction of a Face Showing a Healed Wound', Journal of Archaeological Science 30.10 (2003), 1343-8. 
and exhibited no evidence of infection. There was also a well-healed fracture to the mandible from the right first incisor running inferiorly through the corpus. This injury was probably the result of the blade wound to the left side of the mandible. Towton 16 was reconstructed and depicted with an extensive soft tissue scar and related drooping due to severance of facial nerve branch/es. Knüsel and Boylston state that the wounds seen on the skeletal remains of the Towton soldier suggest some knowledge of the effective treatment of battle injuries, as they do not exhibit any evidence of infection. ${ }^{47}$ They claim that treatment on the battlefield was the province of the barber surgeon and that Towton 16 may have had preferential access due to his social standing. They also suggest that treatment consisted of wound cleaning with oil and the application of a salve or plaster with lint and a bandage and that herbs or roots with healing properties may have been applied to the wound. The form of the healed wound was modelled to indicate that it had been treated with the appropriate medicine of the time, leaving a rather rough and heavily scarred face (see Fig 9.1). It is possible that the face of Towton 16 was more significantly affected than represented and there may have been more extensive tissue necrosis across the upper face and side of the nose due to the damage to the facial vessels and corresponding muscle wastage caused by the decreased blood supply (ischaemia).

[INSERT FIG $9.1 \mathrm{a}$ and $\mathrm{b}$ ABOUT HERE]

${ }^{47}$ C. Knüsel and A. Boylston, 'How has the Towton Project Contributed to our Knowledge of Medieval and Later Warfare?', in Blood Red Roses, ed. Fiorato, Boylston and Knüsel, 169188. 

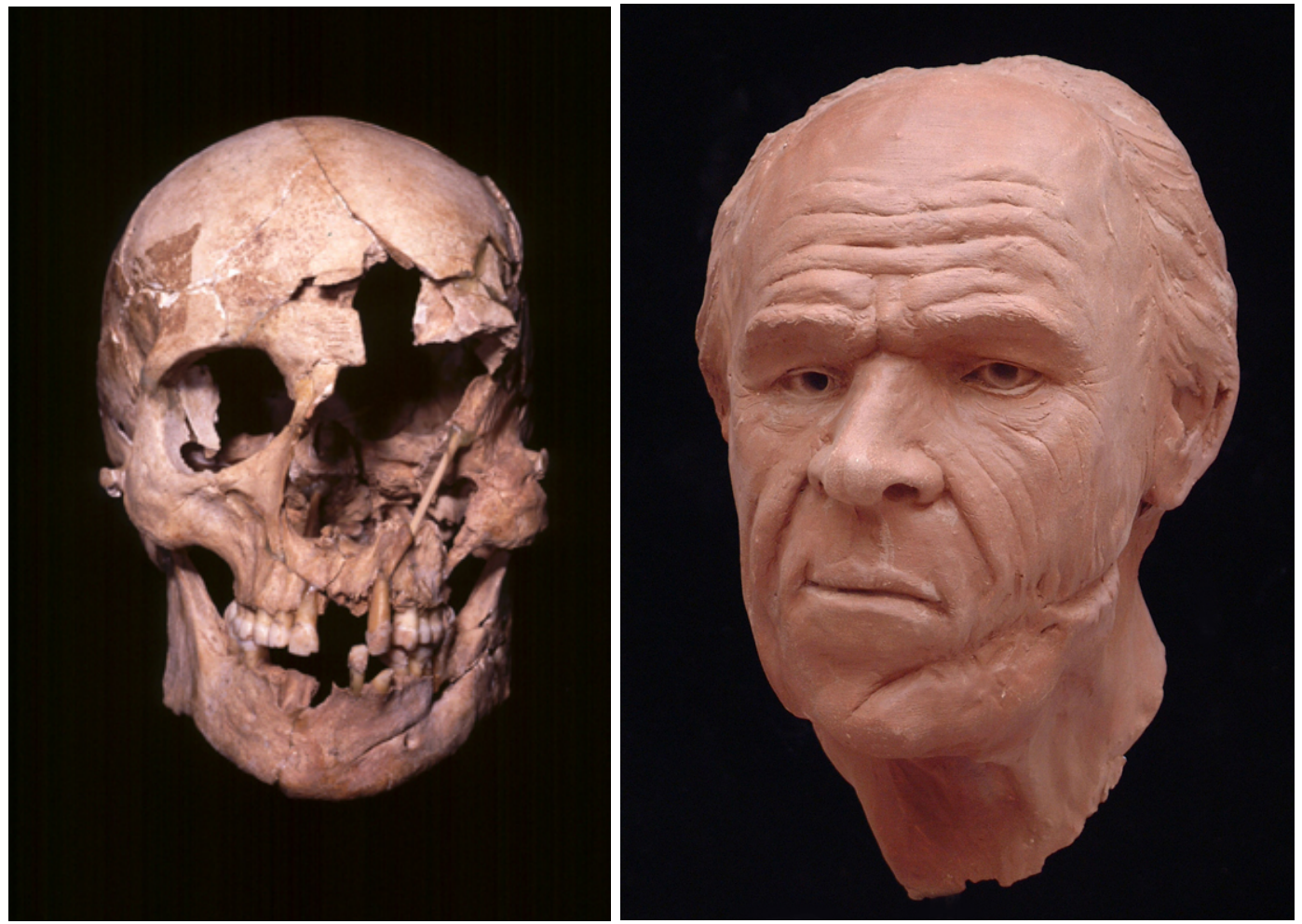

Figure $9.1 \mathrm{a}$ and b: The skull (left) and facial depiction (right) of the Towton 16 soldier Images courtesy of the University of Manchester

\section{Disease in archaeological facial depiction}


Signs of disease to skulls in archaeological investigation are well documented, including leprosy ${ }^{48}$ syphilis,${ }^{49}$ carcinomas,${ }^{50}$ Paget's disease,${ }^{51}$ periodontal disease,${ }^{52}$ infection, ${ }^{53}$

${ }^{48}$ D. L. Weiss and V. Møller-Christensen, 'Leprosy, Echinococcosis and Amulets: a Study of a Medieval Danish Inhumation', Medical History 15.3 (1971), 260-7.

${ }^{49}$ T. Anderson, C. Arcini, S. Anda, Å. Tangerud and G. Robertsen, 'Suspected Endemic Syphilis (Treponarid) in Sixteenth-Century Norway', Medical History 30.3 (1986), 341-50.

${ }^{50}$ L. Kilgore, R. Jurmain and D. Van Gerven, 'Palaeoepidemiological Patterns of Trauma in a Medieval Nubian Skeletal Population', International Journal of Osteoarchaeology 7.2 (1997), 103-114; P. Hacking, 'A Pituitary Tumour in a Medieval Skull', International Journal of Osteoarchaeology 5.4 (1995), 390-3; T. Anderson, 'A Medieval Example of Meningiomatous Hyperostosis', British Journal of Neurosurgery 5.5 (1991), 499-504.

${ }^{51}$ J. L. Price, 'The Radiology of Excavated Saxon and Medieval Human Remains from Winchester', Clinical Radiology 26 (1975), 363-70; J. Byock, 'The Skull and Bones in Egil's Saga: A Viking, a Grave, and Paget's Disease', Viator 24 (1993), 23-50.

${ }^{52}$ S. Sagne and G. Olsson, 'Studies of the Periodontal Status of a Medieval Population', Dentomaxillofacial Radiology 6.1 (1977), 46-52.

${ }^{53}$ M. Djurić-Srejić and C. Roberts, 'Palaeopathological Evidence of Infectious Disease in Skeletal Populations from Later Medieval Serbia', International Journal of Osteoarchaeology 11.5 (2001), 311-320. 
scurvy ${ }^{54}$ and tuberculous osteitis. ${ }^{55}$ There are also some examples where facial depiction has been utilised to illustrate these conditions and pathological conditions depicted on the face can shed light on the social, medical and cultural life of an individual from the past. ${ }^{56}$ The Surgeons' Hall Museum in Edinburgh houses a skull documented as 'Neanderthaloid' 57 This skull was given to the College by David M. Greig, a former conservator of Surgeons' Hall Museum, who obtained it from a 'medical friend, who had inherited it without knowledge of its origin'. The skull was described as having Neanderthal characteristics, with features such as the low forehead and heavy brow ridge. The back of the skull was also described as protruding at the base. In 2008, part of the mystery of this skull was solved when it was sent away for radiocarbon dating; the results showed that the skull was that of a much more modern human, dating from the mid-17th century, as opposed to being from a Neanderthal. ${ }^{58}$ In 2012, the skull was assessed at the University of Dundee and was

${ }^{54}$ D. J. Ortner and M. F. Ericksen, 'Bone Changes in the Human Skull probably resulting from Scurvy in Infancy and Childhood', International Journal of Osteoarchaeology 7.3 (1997), 212-220.

${ }^{55}$ J. D. Schuster, T. A. Rakusan, T. Chonmaitree and Q. T. Box, 'Tuberculous Osteitis of the Skull Mimicking Histiocytosis X', Journal of Pediatrics 105.2 (1984), 269-71.

${ }^{56}$ C. Needham, C. Wilkinson and C. J. Knüsel, 'Reconstructing Visual Manifestations of Disease from Archaeological Human Remains', Journal of Audiovisual Media in Medicine 26.3 (2003), 103-107.

${ }^{57}$ Surgeons Hall Museum. 'The Enigma of the Neanderthaloid Skull (GC 9413). (8 October 2014). https://surgeonshallmuseum.wordpress.com/2014/10/08/the-enigma-of-theneanderthaloid-skull-gc-9413/ [accessed 31/3/2017]. ${ }^{58}$ Ibid. 
determined as a young adult male, displaying characteristics associated with otopalatodigital spectrum disorder (OPD). Frontometaphyseal dysplasia (FMD) was determined as the most likely condition within this spectrum disorder. ${ }^{59}$ The cardinal manifestations of OPD include a deformed palate, prominent brow ridges, widely spaced and downward slanting eyes, a wide nasal bridge and an under-developed lower jaw. ${ }^{60}$ In general, these disorders do not affect intellect and may involve hearing loss and other skeletal abnormalities involving the fingers and/or toes (digits). Additional FMD manifestations seen on this skull included thickening of the cranium, under-pneumatisation of the mastoid processes (small neck attachments) and small, missing and misaligned teeth. ${ }^{61}$ The mandible was absent from this specimen in the Surgeons' Hall Museum, but in FMD the mandible is described as

\footnotetext{
${ }^{59}$ M. Roscoe, 'Differential Diagnosis of an Unknown $17^{\text {th }}$-Century Pathological Skull'
} (Honours Dissertation, University of Dundee, 2012); A. Davison, '3D Facial Depiction of a Specimen Displaying Frontometaphyseal Dysplasia' (MSc Forensic Art thesis, University of Dundee, 2012).

${ }^{60}$ Robertson, S. 'Otopalatodigital Spectrum Disorders'. Gene Reviews 2005-2013, https://www.ncbi.nlm.nih.gov/books/NBK1393/ [accessed 31/3/2017].

${ }^{61}$ A. Verloes et al., 'Fronto-otopalatodigital Osteodysplasia: Clinical Evidence for a Single Entity Encompassing Melnick-Needles Syndrome, Otopalatodigital Syndrome Types 1 and 2, and Frontometaphyseal Dysplasia’, American Journal of Medical Genetics 90 (2000), 407422; S. Robertson, 'Otopalatodigital Syndrome Spectrum Disorders: Otopalatodigital Syndrome Types 1 and 2, Frontometaphyseal Dysplasia and Melnick-Needles Syndrome'. European Journal of Human Genetics 15 (2007), 3-9. 
micrognathic (under-developed) with anterior constriction (pointed chin). ${ }^{62}$ The temporomandibular joints (where the lower jaw articulates with the cranium) were flat and deformed, suggesting that there was limited mandibular movement and the missing, absent and misaligned teeth further suggested that this individual would not be able to chew food effectively. If this person suffered from FMD then it is likely that he also had joint deformities called contractures that restrict the movement of certain joints, bowed limbs, an abnormal curvature of the spine (scoliosis), and abnormalities of the fingers and hands ${ }^{63}$. In addition to skeletal abnormalities, individuals with FMD may have obstruction of the ducts between the kidneys and bladder, heart defects, or problems with breathing. ${ }^{64}$ This individual had therefore reached adulthood without the ability to chew food and with limited movement and mobility. This suggested that this individual must have had someone who provided soft food/liquids and tended to his personal care. Davison ${ }^{65}$ depicted the living face of this young man using digital facial reconstruction (see Fig. 9.2), estimating the mandible using CT scans from individuals with FMD, modelling anatomical structures and following anthropometrical standards. In addition to evaluation of his facial appearance and diagnosis of his likely condition, the interpretation and analysis of this skull provided a rare insight into the care of children from the $17^{\text {th }}$ century.

${ }^{62}$ R. J. Gorlin and M. M. Cohen Jnr, 'Frontometaphyseal Dysplasia: a New Syndrome', American Journal of Diseases of Children 118 (1969), 487-494; D. M. Danks et al., 'Frontometaphyseal Dysplasia: A Progressive Disease of Bone and Connective Tissue', American Journal of Diseases of Children 123 (1972), 254-8.

${ }^{63}$ Robertson ‘Otopalatodigital Spectrum Disorders’ (2005).

${ }^{64}$ Ibid.

${ }^{65}$ Davison, '3D Facial Depiction'. 
[INSERT FIG $9.2 \mathrm{a}$ and $\mathrm{b}$ NEAR HERE]
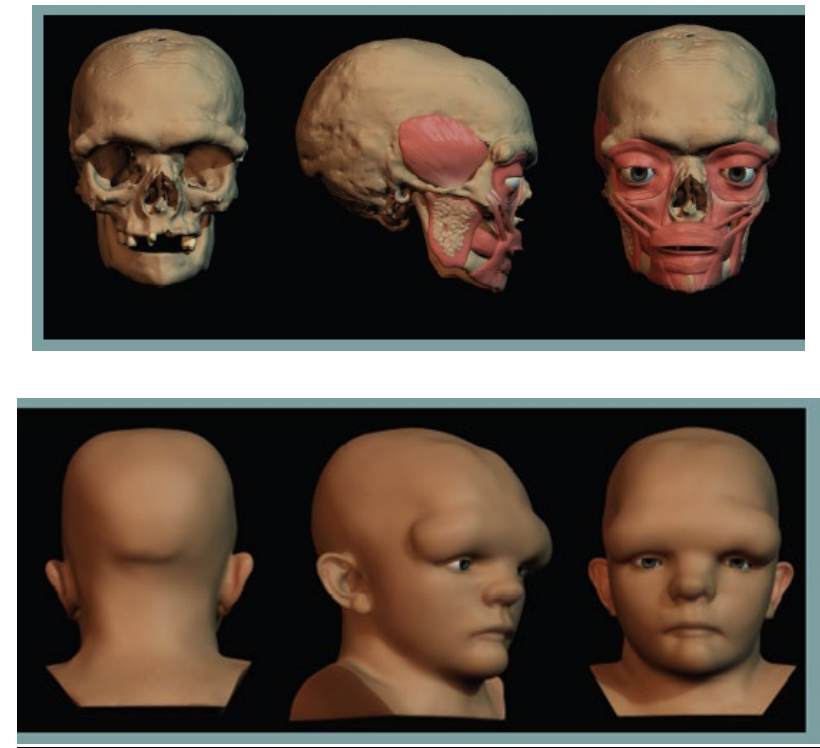

Figure 9.2: The facial depiction of the skull from the Surgeons' Hall Museum, Edinburgh (after Davison, 2012)

Some osteological assessments of craniofacial disease in archaeological investigations have been controversial, and this controversy may demonstrate our discomfort with the interpretation of facial disfigurement in ancient populations. One such example is the chariot burial excavation in 2001 funded by English Heritage in Wetwang, East Yorkshire. ${ }^{66}$ The excavation uncovered the grave of an Iron Age chief, who was buried alongside her richly decorated chariot in the fourth century BC. ${ }^{67}$ The aristocratic Celt was female, 35 to 45 years of age, 5 feet 9 inches tall and she may have had a facial disfigurement. She was laid in a crouched position, head to the south, on a mat or blanket at the southern end of the grave

${ }^{66}$ J. D. Hill, 'Wetwang Chariot Burial', Current Archaeology 15.178 (2002), 410-412.

${ }^{67}$ D. Derbyshire, 'Chariot Queen's Grave Unearthed'. The Telegraph (7 April 2001), http://www.telegraph.co.uk/news/uknews/1310654/Chariot-queens-grave-unearthed.html [accessed 31/3/2017]. 
pit. ${ }^{68}$ An iron mirror was rested against her legs, joints of pig were placed on her upper body and the dismantled chariot was arranged around her. ${ }^{69}$ The chariot was particularly ornate and was decorated with coral from the Mediterranean, and the grave also contained remains of a harness for two horses, including two bronze bits with iron cores and five bronze rein rings. It is thought that this chariot may have been the Iron Age equivalent of a state coach, used to take the queen to her final resting place. It may have been placed in the grave to help her pass to the afterlife. ${ }^{70}$ There has been very little serious research on gender in Iron Age societies in UK contexts, but this burial raised major questions about the role and status of women in that period. $^{71}$

The skull of the Iron Age chief was fragmented and when the skull was reassembled it appeared distorted, with the right side longer than the left. It is not uncommon for skulls in certain burial conditions to exhibit plastic deformation when subjected to external forces, ${ }^{72}$ and after death, bone resilience progressively diminishes. ${ }^{73}$ In fact, bones are able to undergo

${ }^{68}$ Hill, 'Wetwang'.

${ }^{69}$ Ibid.

${ }^{70}$ Derbyshire, 'Chariot Queen’s Grave'.

${ }^{71}$ Hill, 'Wetwang'

${ }^{72}$ M. Jurda, P. Urbanová and M. Králík, 'The Post-Mortem Pressure Distortion of Human Crania uncovered in an Early Medieval Pohansko (Czech Republic) Graveyard', International Journal of Osteology 25.4 (2015), 539-49.

${ }^{73}$ T. A. J. Crist, A. Washburn, H. Park, I. Hood and M. A. Hickey, 'Cranial Bone

Displacement as a Taphonomic Process in Potential Child Abuse Cases', in Forensic Taphonomy: The Postmortem Fate of Human Remains, ed. W. Haglund and M. Sorg (Boca Raton, Boston, London, New York and Washington DC: CRC Press, 1997), 319-336. 
post-mortem distortion of the entire original geometry while the integrity remains relatively intact and several such cases have been described in the literature. ${ }^{74}$ One notable example is Ötzi, the Iceman, discovered in the Alps in 1991, who exhibited localized post-mortem distortions of the facial skeleton and the basicranium. ${ }^{75}$ Lynnerup states that "under these conditions, etiological attribution of pathology and trauma lack certainty'. ${ }^{76}$ Jurda and colleagues described post-mortem distortion patterns to crania and found that the shape change associated with the in situ orientation agreed with the compression of the cranial shape in the direction of the vertical, i.e. the Earth's gravity. ${ }^{77}$ However, they also found that the original morphology of the cranium affected the final resting position recorded on site. For example, the crania with broad and short braincases and flat occipital regions were more inclined to persist in their supine burial positions since larger contact surface provided them

${ }^{74}$ G. W. Weber and F. L. Bookstein, Virtual Anthropology: A Guide to a New Interdisciplinary Field (Vienna: Springer, 2011); J. L. Thompson and B. Illerhaus, 'A New Reconstruction of the Le Moustier 1 Skull and Investigation of Internal Structures using 3-DmCT Data', Journal of Human Evolution 35.6 (1998), 647- 665; M. S. Ponce de León and C. P. E. Zollikofer, 'New Evidence from Le Moustier 1: Computer-Assisted Reconstruction and Morphometry of the Skull', The Anatomical Record 254.4 (1999), 474-489.

${ }^{75}$ H. Wilfing, H. Seidler, D. Nedden, G. Weber, H. Preuschoft, W. Platzer, R. Knapp, G. Haouser and W. A. Murphy, 'Cranial Deformation of the Neolithic Man from the Hauslabjoch', Collegium Anthropologicum 18.2 (1994), 269-282.

${ }^{76}$ N. Lynnerup, 'Medical Imaging of Mummies and Bog Bodies, a Mini-Review', Gerontology 56 (2010), 441-8.

77 Jurda et al., 'Post-Mortem Pressure'. 
with stability, while the long-headed specimens with the protruded occipital region were unstable in their original positions and slid onto their side.

The Wetwang skull was excavated lying on its left side and there was a bilateral difference in the length of the facial skeleton. However, the rear of the cranium did not appear distorted and the overall pattern did not appear consistent with vertical compression from its right side down to the left. Whilst bone can be distorted in shape by post-mortem pressure, there is no evidence that bone can be stretched in the pattern seen for the Wetwang skull, and the pathologist determined that the most likely cause of the asymmetry was a soft tissue growth on the right side of the face leading to related bone remodelling (see Fig 9.3). Dr Robert Stoddart, from the University of Manchester, suggested a haemangioma as the most likely diagnosis. $^{78}$

\section{[INSERT FIG 9.3 ABOUT HERE]}

Past interpretations of Iron Age grave goods have linked mirrors with women of high status ${ }^{79}$ but it is possible that this was an association to her facial disfigurement. It cannot be ignored that mirrors are utilised to reflect appearance and by the end of her life her facial appearance would have been different and noticeable. Since there was academic disagreement at the time of the excavation as to whether the skull exhibited post-mortem or ante-mortem deformation, the condition was not sensationalised with extreme texture or

\footnotetext{
${ }^{78}$ Meet the Ancestors, series 5, episode 1: The Chariot Queen (27 November 2007). http://www.bbc.co.uk/programmes/b008fj5s [accessed 31/3/2017].

${ }^{79}$ C. Fox, Pattern and Purpose: a Survey of Early Celtic Art in Britain (Cardiff: National Museum of Wales, 1958); J. Joy, Iron Age Mirrors: A Biographical Approach (Oxford:
} Archaeopress, 2010). 
condition, and if this woman had a haemangioma then it is possible that it was more severe than shown in the depiction. It may be that the mirror is a statement of her facial difference and if this interpretation is correct then this provides an interesting insight into the status of people with facial disfigurement in ancient populations, and disagrees with previous theories linking disfigurement with loss of status and exclusion. ${ }^{80}$ In this case her high status could have trumped her facial disfigurement, or it may be that ancient populations were more tolerant and empathetic to facial disfigurement than previously thought.

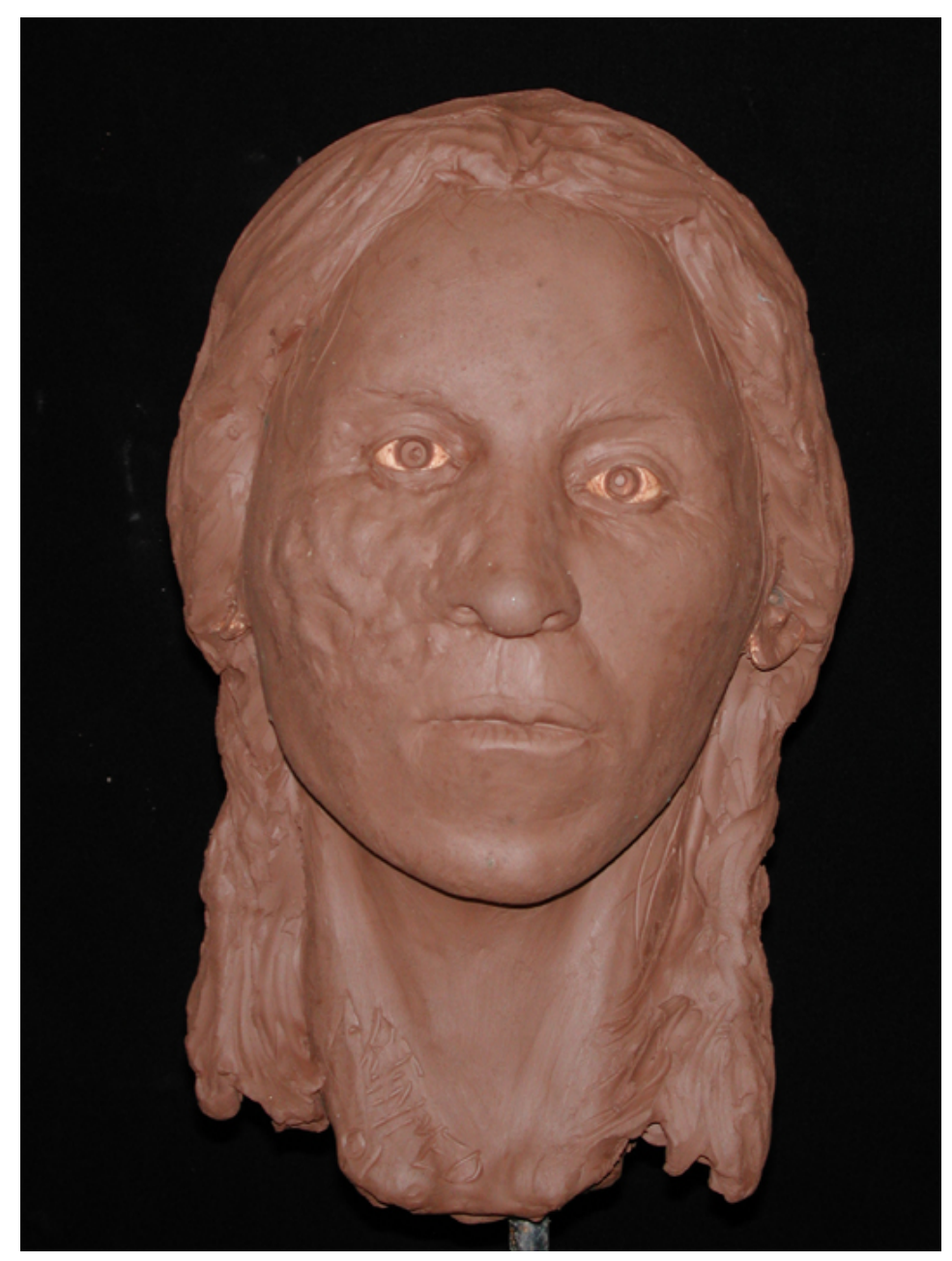

Figure 9.3: The facial depiction of the Wetwang Chariot Queen

${ }^{80}$ Craig and Craig, 'Diagnosis and Context'. 


\section{Deliberate body modification in archaeological facial depiction}

Signs of deliberate craniofacial modification are well documented in archaeological investigations, including trepanation, ${ }^{81}$ dental filing ${ }^{82}$ and cranial deformation. ${ }^{83}$ It is well established that some cultural practices can leave their mark on the skeleton as altered morphology. Cranial deformation is the result of pressure influence on bone modelling during childhood and can be accidental or intentional. Accidental modification may be the result of the long term influence of cradle devices, and intentional modification may be due to the

${ }^{81}$ J. W. Verano, 'Trepanation in Prehistoric South America: Geographic and Temporal Trends over 2000 Years', Trepanation History, Discovery, Theory 17 (2003), 223-236; V. A. Andrushko and J. W. Verano, 'Prehistoric Trepanation in the Cuzco Region of Peru: a View into an Ancient Andean Practice', American Journal of Physical Anthropology 137.1 (2008), 4-13; W. T. Clower and S. Finger. 'Discovering Trepanation: the Contribution of Paul Broca'. Neurosurgery 49.6 (2001), 1417-1426.

${ }^{82}$ Mower, J. 'Deliberate Ante-Mortem Dental Modification and its Implications in Archaeology, Ethnography and Anthropology'. Papers from the Institute of Archaeology 10 (1999), 37-53; B. C. Finucane, K. Manning and M. Touré, 'Prehistoric Dental Modification in West Africa: Early Evidence from Karkarichinkat Nord, Mali', International Journal of Osteoarchaeology 18.6 (2008), 632-640.

${ }^{83}$ E. J. Dingwall, Artificial Cranial Deformation (London, John Bale, Sons and Danielson, 1931). 
application of bindings or boards resulting in the elongation of the vault. ${ }^{84}$ The bioarchaeological record of South America is characterized by the high frequency of individuals with a variety of cranial deformations concentrated in three areas (North-West, Central-West and South) of this subcontinent, and this practice is thought to have been aesthetic and related to high status. ${ }^{85}$

One case of an unusual artefact from Elgin Museum in Scotland demonstrates this phenomenon. Elgin museum houses a large glass dome containing a mummified human body in a foetal position, and this was donated to the museum in 1846 by James Fletcher Esq of Rosshaugh, Ross-shire, who was born in Elgin. Along with his brother, James founded a trading house in Liverpool, and became involved in the importing of alpaca wool from the Andes of South America. The wool of the alpaca was used to produce a lustrous cloth, which in the 1830s was fashionable and in great demand. During a visit to Elgin in 1846, James donated a number of items from Peru to the Elgin Museum; a case of 12 Peruvian birds, two dressed figures, six specimens of gold, and various other items. The glass dome also contains a memorandum notice stating:

This mummy was taken from a cave in Maretasse, an Islet of Lake Titicaca, adjoining the small peninsula of Capachica, about 10 leagues from the city of

${ }^{84}$ D. Brothwell, 'Possible Evidence of a Cultural Practice Affecting Head Growth in Some Late Pleistocene East Asian and Australasian Populations', Journal of Archaeological Science 2 (1975), 75-7.

${ }^{85}$ S. I. Perez, 'Artificial Cranial Deformation in South America: a Geometric Morphometrics Approximation', Journal of Archaeological Science 34.10 (2007), 1649-58; C. Torres-Rouff, 'Shaping Identity: Cranial Vault Modification in the Pre-Columbian Andes' (Unpublished PhD thesis, University of California, 2003). 
Puno, the capital of the department. There was a rope, formed of some vegetable substance, tied around the back and knees, which caused the loss of skin on these parts. The few ignorant and superstitious inhabitants of the Islet regarded the mummy with a species of veneration and its loss was immediately discovered and deeply lamented. The crops were not so abundant that season as they were in some previous years, and this circumstance was attributed to the loss of the Gentil, a term equivalent to Pagan, dead body. Being convinced amongst themselves that the act must have been perpetrated by some person not an inhabitant of the Islet, their suspicions, which turned out to be well-founded, fell upon an Englishman, at the time in Capachica, and to save himself from the fury of the Indians he was obliged to leave that part of the country. The head from its peculiar formation is very singular. The local traditions led one to suppose that this mummy had been interred at a period antecedent to the Reign of the Incas. It is a body of a female, of the computed stature of five foot four inches. The extremities are doubled up so to occupy the smallest possible space. The head is of extraordinary height and of the sugar-loaf form, which seems to have been imparted to it by pressing on the occiput during infancy. From Professor Owen's description of the skulls of the South American tribes this individual would appear to have been of the Carib race. The complete preservation of the subject has probably been accomplished by baking amidst the slow combustion of herbs and substances possessing antiseptic properties.

The mummy was well preserved with some destruction of the soft tissues and evidence of fabric binding marks across the body. This along with the foetal positon suggest that this was an unwrapped bundle mummy. The teeth and skeleton were in excellent condition and the 
mummy was mounted onto a wooden pole pushed up through the pelvis. Experts from the University of Dundee, in collaboration with the Scottish Universities Environmental Research Centre, carried out a full analysis of the mummy in 2012, using CT imaging, carbon dating, anthropology and facial depiction. ${ }^{86}$ The skull of the mummified girl was sugar-loaf shaped, and cranial modification is known to have been a common practice in Peru, typically suggesting high status in the Aymara tribes. The head would be deformed during infancy using head boards or bindings and such an annular modification is produced when bands are wrapped around the forehead and the back of the skull to force the bone to grow upright. The skull also exhibited shovel-shaped incisors, round orbits, a tented nasal root and a flat midface; all characteristics associated with native South American populations. It was a common Aymara custom to inter the dead in a seated or squatted position, with the head pressed down between the knees and arms placed crosswise over the breast, and the foetal position originated as a desire to facilitate rebirth. A common belief is that their first ancestors had risen either from certain fountains and lakes (eg, Lake Titicaca), or from caves or clefts in certain rocks of extraordinary size, and each person, after death, became a God, who protected the tribe. Each God was given its own Chullpa or shrine. It seems likely therefore that this mummy was an important young woman from the Aymara culture. The facial depiction by Tobias Houlton showed the cranial deformation and a facial appearance similar to contemporary Peruvian faces.

\footnotetext{
86 'Mummy Returns to Elgin'. The Northern Scot (25 September 2015). http://www.northernscot.co.uk/Features/People-and-Places/Mummy-returns-to-Elgin-25092012.htm [accessed
} $31 / 3 / 2017]$ 


\section{Summary}

Facial depiction from the interpretation of skeletal remains can play an important part in multi-disciplinary archaeological investigations and provides an alternative way to reconstruct stories, lives and people from the past. Each investigation will include numerous agendas, and a facial depiction can counter or justify strongly held beliefs about an historical figure and/or indicate aspects of lifestyle and community in ancient populations. The depiction of people from the past with facial difference can provide insight into medical treatment, status, social cohesion and cultural practice.

In this way the minor trauma exhibited on the skull of St Nicolas lead to the perpetuation of the story of a persecuted Christian saint living in a violent time, and yet his broken nose could also have been the result of a clumsy or drunken accident or childhood injury. This contrasts with the facial depiction of Richard III, where his 'unremarkable' face enabled the creation of a different view of the King at odds with the deformed Shakespearean monster influenced by and part of Tudor propaganda. Some examples of the depiction of pathological conditions on the face have added weight to theories relating to medical treatment, cultural traditions and caring communities by demonstrating extensive healed battle wounds in medieval soldiers, deliberate head deformation fashions and the longevity of people with disabling and disfiguring congenital conditions. However, occasionally the facial depiction does not fit with accepted archaeological theory and this can lead to the re-evaluation of accepted norms or the marginalisation of the depiction. One such example is the Iron Age Chariot Queen case, where her controversial facial appearance may suggest tolerance, empathy and acceptance of facial disfigurement in ancient populations, especially when the individual is high status and important to the community. In general the comparison between ancient and contemporary 
populations continues to inform our perceptions, interpretations and interrogations of facial difference. 